\title{
New Approaches for Harmonics Reduction in Solar Inverter
}

\author{
Mr. Rohitkumar S. Patil ${ }^{1}$, Mr. Rajan J. Devi ${ }^{2}$ \\ PG Student, ZEAL College of Engineering, Narhe, Pune, Maharashtra, India \\ Associate Professor (Electronics), Department of Electronics Engineering; Karmaveer Bhaurao Patil College of \\ Engineering, Satara, Maharashtra, India

\begin{abstract}
The aim of this paper is to compare two approaches such as cascaded H-Bridge Inverter and second uses new Multi-level Scheme for pulse width modulated voltage source inverter. This paper describes the simulation of above mentioned modules in SIMULINK/MATLAB Software. Comparison is done in terms of Total Harmonic Distortion (THD) in output load voltage, active Power and reactive Power. Better THD along with larger active and reactive powers produced in second scheme as compares to a certain stages of the first scheme.
\end{abstract}

Index Terms: Multilevel inverter, H-Bridge inverter, Total Harmonic Distortion (THD), Simulink Model.

\section{INTRODUCTION}

In order to increase the use of renewable energy sources such as solar, wind, biomass etc; it has led to global effort towards increasing the same. According to demand of electricity, by using solar PV cells DC power is converted into $\mathrm{AC}$ power \& then can be insert it into grid or used in isolated load. There are number of methods are available to convert AC power to $\mathrm{DC}$ power conversion. To provide the required load voltage, inverter system works in standalone mode or grid connected mode. In load scheduling condition or grid off condition, the inverters works in standalone mode and provide the required power to the load. Being major of the power available through renewable systems is in DC form, inverters are preferred instead of alternators. The system presented here is a DC to AC multilevel inverter controlled by PWM (PulseWidth Modulation).[6]

First approach is cascaded $\mathrm{H}$ bridge inverter. It is conventional topology in family of multilevel \& multiphase inverter. The cascade topology allows the use of several levels of DC voltages to synthesize a desired AC voltage. The DC levels are considered to be identical since all of them are fuel cells or photovoltaic, batteries, etc.[8]

Review of approaches for harmonics reduction in solar inverter are described in the second section named as literature review. Proposed system for harmonic reduction in solar inverter is described in Methodology section. Experimentation and Results are discussed in next section.

\section{LITERATURE REVIEW}

In order to obtain multilevel output voltage, single phase multilevel inverter for using as a voltage harmonic source, a switching strategy based on calculating switching angles is explained .Simulation and experimental results of multilevel voltage waveforms are given for 15, 31 and 127 levels. The proposed topology produce output voltages with low THD values as well as produces the required harmonic components on the output voltage. The output voltage as well as the required specific harmonics controlled by angles. With the required harmonic components, the proposed inverter structure is simulated for various functions. Proposed inverter structure realized simulated functions and THD values of the output voltage waves [1].

In the area of high-power medium-voltage energy control, emerged recently as a very important alternative is Multilevel inverter technology. This paper discussed Emerging topologies like asymmetric hybrid cells and soft-switched multilevel inverters [10]. The most important topologies like diode-clamped inverter (neutralpoint clamped), capacitor-clamped (flying capacitor), and cascaded multicell with separate dc sources are presents here. Most relevant control and modulation methods developed for this family of converters like Multilevel sinusoidal pulse width modulation, multilevel selective harmonic elimination, and space-vector modulation presents in this paper [2].

Multilevel line commutated inverters for renewable energy systems have gained popularity in recent times, especially in the distributed generation where a number of batteries, fuel cells, solar cell, and micro-turbines can be connected through a MLC to feed the grid [7]. Multilevel line commutated inverters can synthesize higher output voltage levels and can generate near sinusoidal voltages have gained popularity in recent times, especially in the distributed generation where a number of batteries, fuel cells, solar cell, and micro-turbines can be connected through a MLC to feed the grid. This paper presents Analysis of a grid connected MLC as an inverter having variable dc sources(which can be the output of wind 
IARJSET

International Advanced Research Journal in Science, Engineering and Technology

National Conference on Emerging trends in Electronics \& Telecommunication Engineering (NCETETE 2017)

AGTI's Dr. Daulatrao Aher College Engineering, Vidyanagar Extension, Karad

Vol. 4, Special Issue 2, January 2017

farms, solar panels etc.) presents in this paper. By been done to minimize total harmonic distortion increasing the stages and by varying the delay angles for (THD)[5]. A comparative study of different stages of varying dc input to the multilevel inverter, a Computer MLC for different value of dc input, results has been simulation analysis using SIMULINK/ MATLAB has tabulated and discussed [3].

\section{III.METHODOLOGY}

Fig.1. shows single stage $\mathrm{H}$ bridge Inverter. Fig. 2. Shows Cascaded Multilevel H-Bridge Inverter

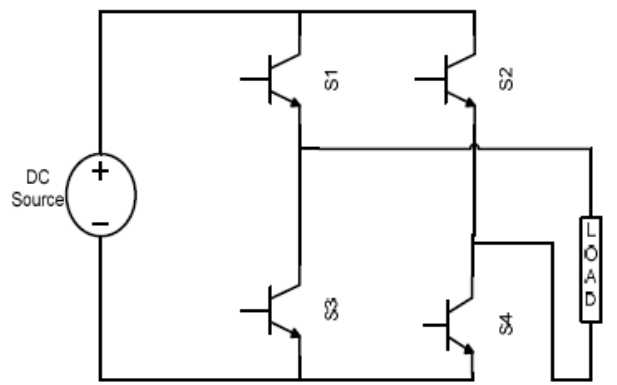

Fig. 1.Single stage H Bridge Inverter [4]



Fig.2. Cascaded Multilevel H-Bridge Inverter [4]



Fig.3. MATLAB Simulation Model for three level 
International Advanced Research Journal in Science, Engineering and Technology

National Conference on Emerging trends in Electronics \& Telecommunication Engineering (NCETETE 2017) AGTI's Dr. Daulatrao Aher College Engineering, Vidyanagar Extension, Karad

Vol. 4, Special Issue 2, January 2017

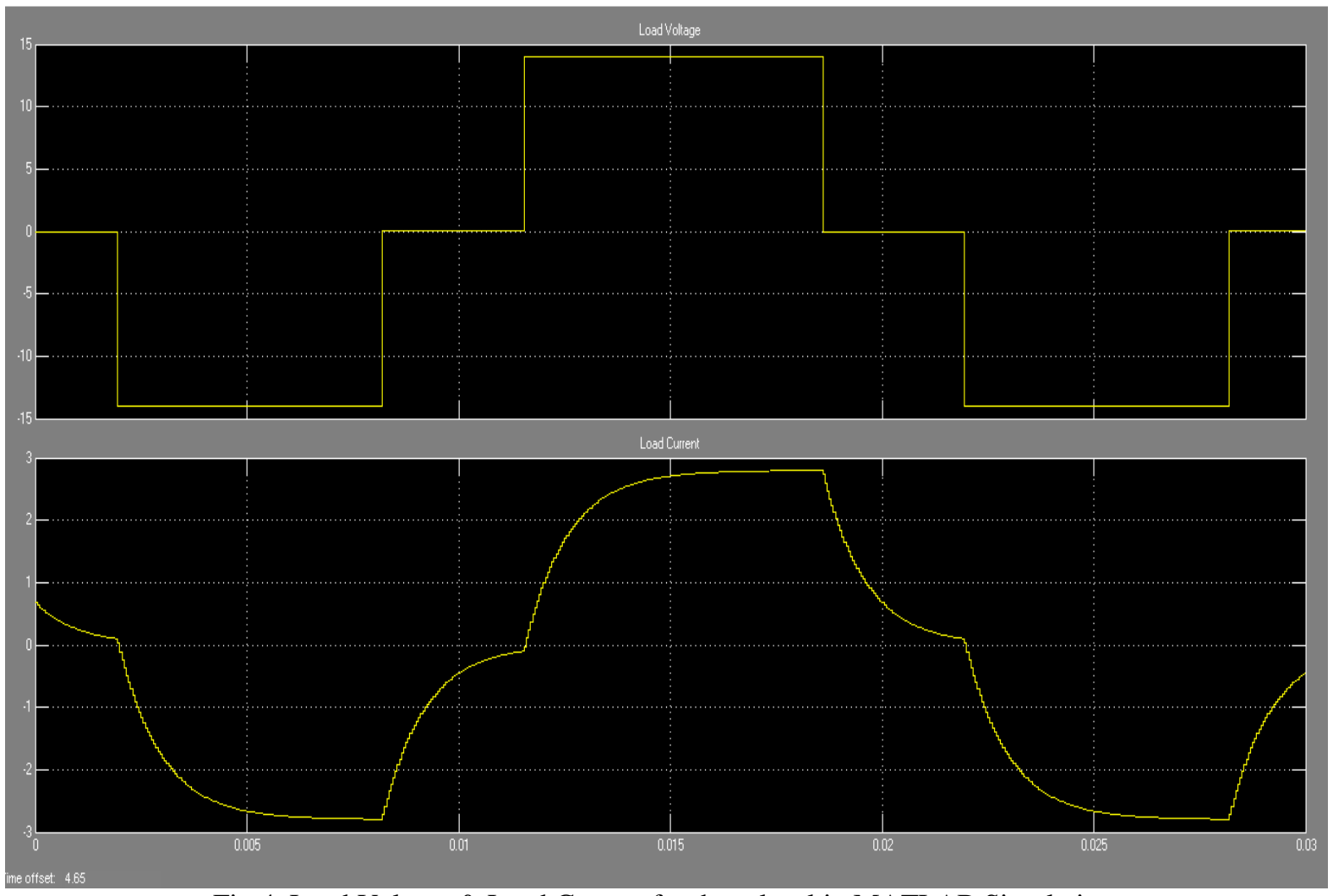

Fig.4. Load Voltage \& Load Current for three level in MATLAB Simulation



Fig.5. MATLAB Simulation Model for Eight levels 
International Advanced Research Journal in Science, Engineering and Technology

National Conference on Emerging trends in Electronics \& Telecommunication Engineering (NCETETE 2017) AGTI's Dr. Daulatrao Aher College Engineering, Vidyanagar Extension, Karad

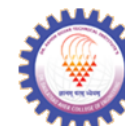

Vol. 4, Special Issue 2, January 2017
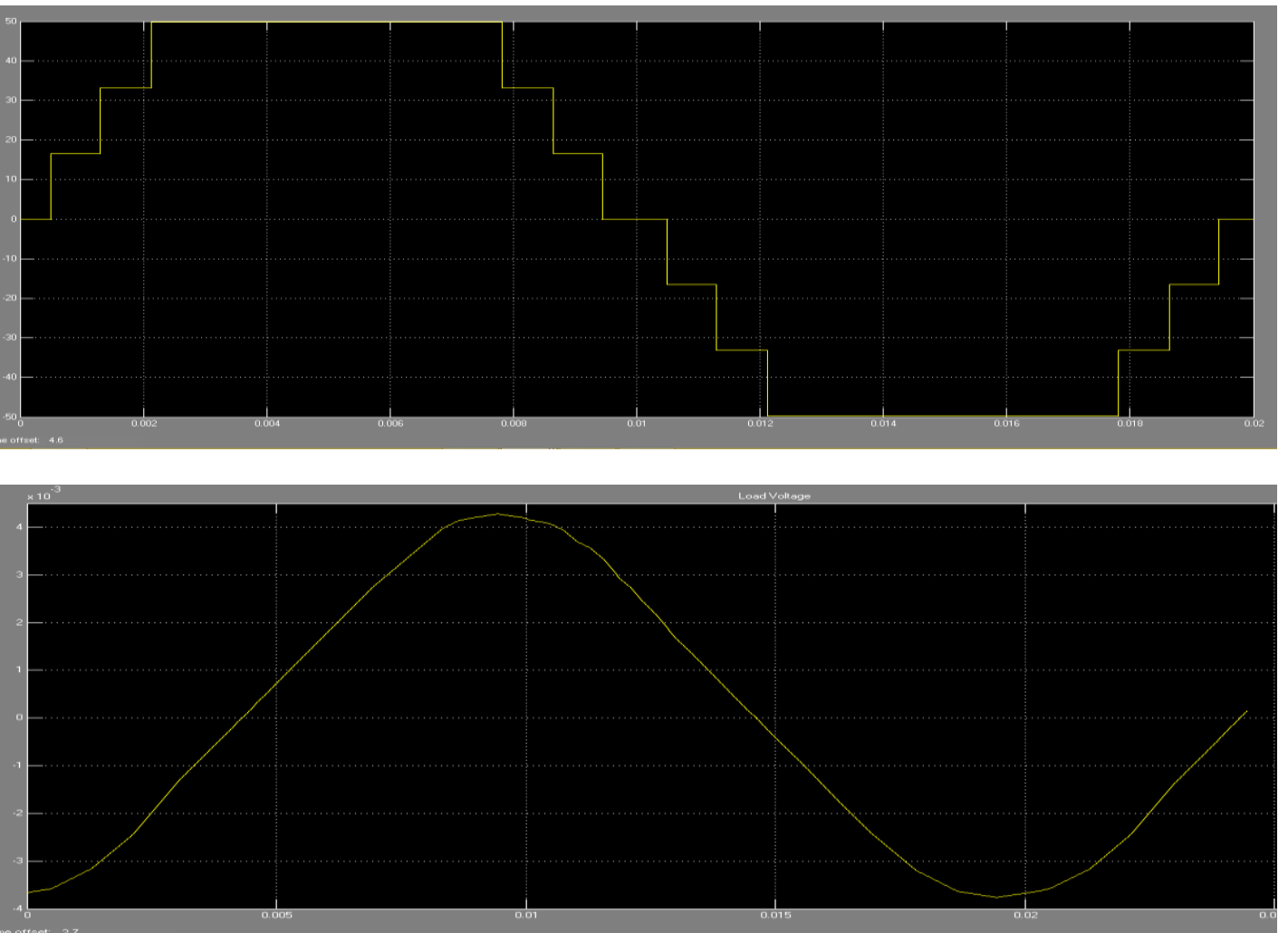

Fig.5. Load Voltage \& Load current for Eight levels in MATLAB Simulation

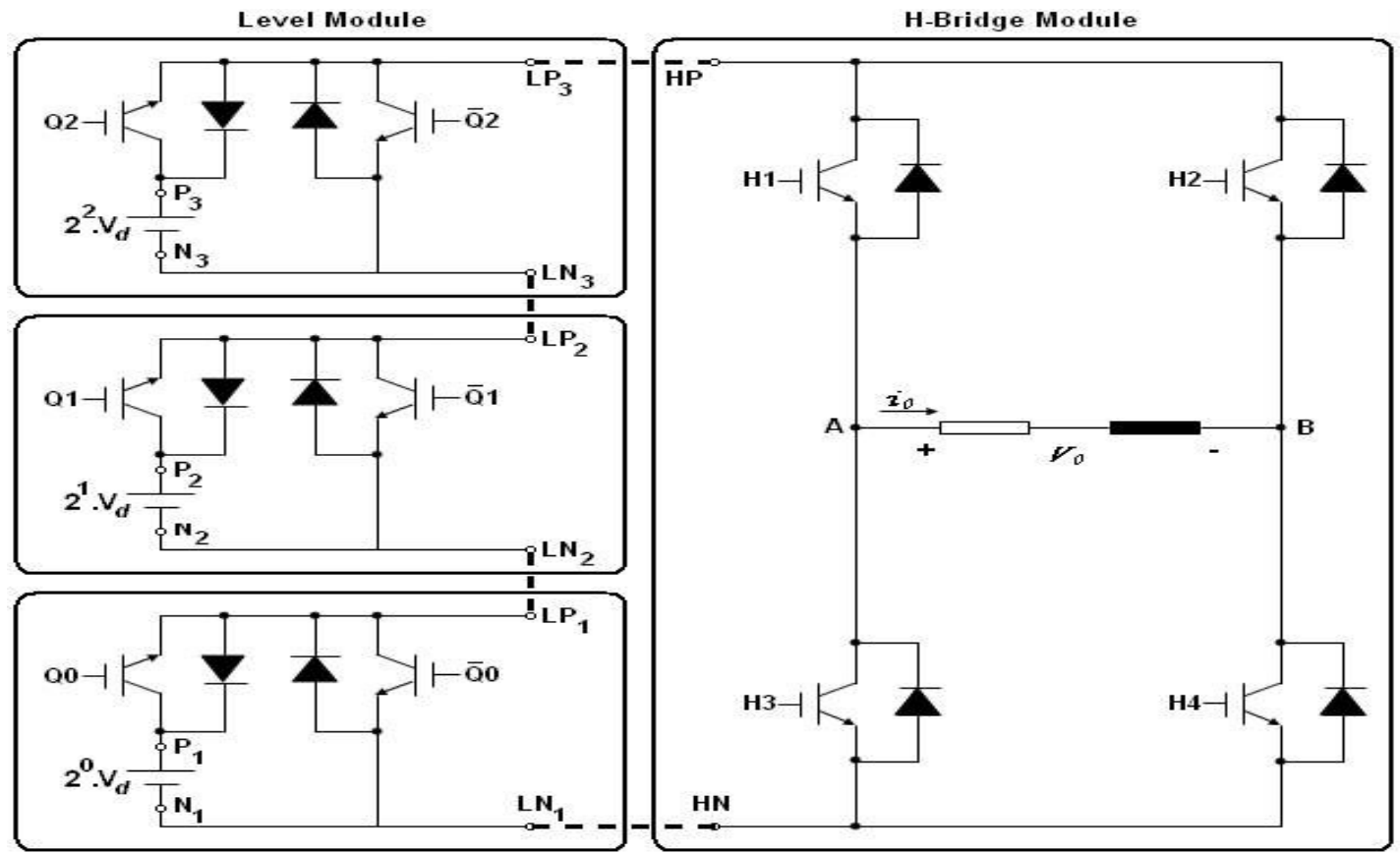

Fig.7. Proposed Multilevel Inverter

Fig.3. shows Simulation model for three levels of inverter. Fig.4. Shows the output voltage \& load current for the same. Fig.5. shows the MATLAB Simulation model for eight levels.

Fig.6. shows the load voltage \& Load current for eight level inverter. Fig.7. shows proposed multilevel inverter diagram for simulation in MATLAB.

\section{IV.CONCLUSION}

In this paper, MATLAB simulation Models for three levels, eight levels are designed. The proposed multilevel inverter is defined here for the further study. The load voltage \& Load currents foe respective multilevel inverter is also shown here. 


\section{ACKNOWLEDGMENT}

I am using this opportunity to express my gratitude to everyone who supported me for writing this research paper. I am thankful for their guidance and invaluably advice during this work. I am sincerely grateful to them for sharing their truthful and illuminating views on a number of issues related to this paper.I express my warm thanks to Prof. Rajan J. Devi for his support and guidance at Department of Electronics Engineering; KBP College of Engineering ,Satara; Maharashtra, India.

\section{REFERENCES}

[1]. Ersoy Besery, Birol Arifoglu, Sabri Camur, and Esra Kandemir Beser Dept. of Electrical Eng., Kocaeli University, Kocaeli, Turkey,' Design and Application of a Single Phase Multilevel Inverter Suitable for using as a Voltage Harmonic Source' Journal of Power Electronics, Vol. 10, No. 2, March 2010.

[2]. José Rodríguez, Senior Member, IEEE, Jih-Sheng Lai, Senior Member, IEEE, and Fang Zheng Peng, Senior Member, IEEE,' Multilevel Inverters: A Survey of Topologies, Controls, and Applications' IEEE TRANSACTIONS ON INDUSTRIAL ELECTRONICS, VOL. 49, NO. 4, AUGUST 2002.

[3]. Abu Tariq, Mohammed Aslam Husain, Mohammad Ahmad, Mohd. Tariq,Department of Electrical Engineering, Aligarh Muslim University (AMU), Aligarh , INDIA,' Simulation and study of a grid connected Multilevel Converter (MLC) with varying DC input' CONFERENCE PAPER - JANUARY 2011.

[4]. Mohammad Ahmad and B. H. Khan, Senior Member, IEEE,"NEW Approaches for harmonics reduction in solar inverter", IEEE Transaction 2012.

[5]. Yeong Jia Cheng and Eng Kian Kenneth Sng, “A Novel Communication Strategy for Decentralized Control of Paralleled Multi-Inverter-Systems", IEEE transactions on power electronics, vol. 21, no. 1,pp.148-156, January 2006

[6]. Frede Blaabjerg, Remus Teodorescu, Marco Liserre and Adrian V. Timbus, "Overview of Control and Grid Synchronization for Distributed Power Generation Systems", IEEE TRANSACTIONS ON INDUSTRIAL ELECTRONICS, VOL. 53, NO. 5, pp.13981409, OCTOBER 2006.

[7]. M.A.A. Younis, N. A. Rahim and S. Mekhilef,"High Efficiency THIPWM Three-Phase Inverter for Grid Connected System”, Dept. of Electrical Power Engineering, UNITEN, Selangor, Malaysia.

[8]. Lidong Zhang, Lennart Harnefors and Hans-Peter Nee, "PowerSynchronization Control of Grid-Connected Voltage-Source Converters", IEEE TRANSACTIONS ON POWER SYSTEMS, VOL. 25, NO. 2, pp.809-820,MAY 2010

[9]. S.Manoharan, Dr.K.Gnanambal , R .Girija, K.P.Ram Prasath,“'Grid Synchronization by Estimation of Positive Sequence Component in Three Phase Signals", International Journal of Innovative Research in Science, Engineering and Technology, Volume 3, Special Issue 3, March 2014.

[10]. Qing-Chang Zhong, Phi-Long Nguyen, Zhenyu Ma, and Wanxing Sheng, "Self- Synchronized Synchronverters: Inverters Without a Dedicated Synchronization Unit", IEEE TRANSACTIONS ON POWER ELECTRONICS, VOL. 29, NO. 2, pp.617-630, FEBRUARY 2014. 